\title{
PHYSICIANS, PATIENTS AND TREATMENTS IN EARLY MEDIEVAL GERMAN (ESPECIALLY BAVARIAN) LEGISLATION
}

\section{Tamás Nótári*}

\section{ABSTRACT}

This study analyses the provisions of some early medieval "German" legislation concerning medical issues, such as healing, diseases and injuries. After a brief introduction, the study discusses the sedes materiae and the issue of dating those German codes (Volksrechte) that constitute the basis of comparison here, namely Bavarian, Visigothic, Langobardic and Alemannian law. Within the context of medical treatment during the early Middle Ages, a brief description is given of early medieval medicine and the physician's legal status as set out in legal and non-legal sources. This is followed by the analysis of the regulation of diseases, miscarriage, bodily injury and other injuries in the lex Baiuvariorum, that is then compared with the provisions of the above mentioned German codes. The study thereafter examines the legal consequences of diseases that influenced the legal capacity and the capability to participate in legal proceedings as well as the position with regard to abortion, the involvement of the physician and the treatment applied by him within the context of the law and folk language terminology regarding bodily injury and injuries.

* Senior Research Fellow of the Institute for Legal Studies of the Centre for Social Sciences of the Hungarian Academy of Sciences; Associate Professor of the Sapientia Hungarian University of Transylvania. 
Keywords: Early medieval medical law; Volksrechte; lex Baiuvariorum; leprosy; abortion; lex Visigothorum; sedes materiae; lex Alamannorum; Codex Euricianus; Edictus Rothari

\section{Introduction}

It should be stated at the outset that in the light of German folk laws as sedes materiae, all the questions that have primary importance concerning either modern or Roman medical law - more specifically the aspects regarding the physician's liability - are addressed in these laws. Knowing the conditions of law in this period, it cannot be expected from these laws, and such an approach would be considered highly unhistorical. On the other hand, owing to the fact that the medical law aspect cannot be grasped in its complexity, it is not possible for the legal historian/philologist to exclude the analysis of folk laws when studying legal history. In addition, the legal nature of the source base clearly makes it the task of the legal historian to carry out extensive research of these leges, making use of the results of the history of language as well as public and social history (in our case, the history of medicine) in order to make these findings available to the aforesaid sciences (the auxiliary sciences for the legal historian).

It is necessary to outline the applied philological method. The objective of the study is primarily legal historical in nature; however, regarding the applied method, philology stricto sensu appears with at least as much weight. "Alle mittelalterliche Forschung ist Philologie", Hermann Heimpel wrote in his foreword to Heinz Quirin's manual, ${ }^{1}$ and we tried to focus on this basic principle, namely the criteria of source analysis and respect for sources. ${ }^{2}$

German folk laws abounded in both anatomical terms and phrases that denoted injuries, their consequences and concomitant symptoms as well as terms that specified diseases, medical equipment and therapeutic methods. Yet the relation between the physician and the patient in ex asse legal aspects was thematised only by Visigothic laws that showed a strong Roman law influence. In the analysis of medical law texts of folk laws, priority should be given to pregnancy and abortion since these texts devoted ample space to the issues that cannot be neglected in terms of law and medicine. Although codes of law provide relatively little information on pathographies themselves, it provides ample details on surgical intervention and damage to health that might have influenced the patient's capability of working, fighting and participation in legal processes.

From among works dealing with German elements of folk laws and the appearance of the terminology of medicine in Volksrechte, the works of Wilhelm

1 Quirin 1950: 4.

2 See, also, Schott 1979: 31; Mitteis \& Lieberich 1966: 73. 
Eduard Wilda, ${ }^{3}$ Jacob Grimm, ${ }^{4}$ Arthur B Schmidt, ${ }^{5}$ Rudolf His, ${ }^{6}$ Sigfrid von Schwanenflügel, ${ }^{7}$ Georg Baesecke, ${ }^{8}$ Dietrich von Kralik, ${ }^{9}$ Ruth Schmidt-Wiegand ${ }^{10}$ and Annette Niederhellmann ${ }^{11}$ should be highlighted.

\section{The sedes materiae}

The date of creation of the lex Baiuvariorum ${ }^{12}$ between 737 and 743 - as suggested by Heinz Löwe and Peter Landau - is supported by ecclesiastical influence far exceeding the impact of German folk laws. It is quite clear from the text of the law that its compiler set out from a knowledge of canon law rules and a clearly circumscribed church organisation. Furthermore, the fact that the compilers of the lex Baiuvariorum also used the lex Alamannorum, ${ }^{13}$ further supports the dating to be between 737 and 743. ${ }^{14}$ Regarding the place of creation of the lex Baiuvariorum, we can accept Peter Landau's hypothesis that this work relation between the monks and the duke's court must have been much closer if we accept that the compilers of the lex Baiuvariorum were the monks of the St Emmeram monastery located at the duke's seat in Regensburg. ${ }^{15}$

Leges Visigothorum is a general name for records of Visigothic law that have survived in various forms. The oldest source left to us is the Visigothic Codex Euricianus, which is attributed by tradition to king Eurich and was created sometime between 469 and $476 .{ }^{16}$ It survived in a sixth century palimpsest codex from Paris in fragments from caput 276 to caput 336. The Codex Euricianus was strongly influenced by Roman law as well, and would arguably later have the greatest impact on other German folk laws. King Leovigild supplemented/corrected the Codex Euricianus at several points, which was then renamed the Codex revisus. This source has, however, not survived. ${ }^{17}$ One of the successors of Leovigild, namely King Reccesvind, published two legal compilations in 654, in which he marked three hundred and nineteen provisions as antiqua and traced them back to Leovigild. ${ }^{18}$

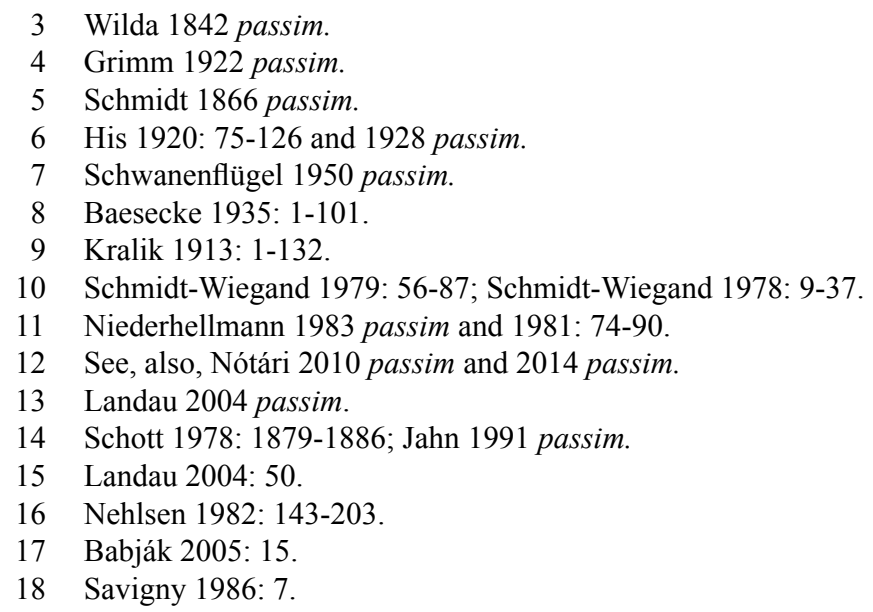


Reccesvind's compilation is referred to in the literature under different names: Lex Visigothorum, ${ }^{19}$ Lex Visigothorum Reccesvindiana, ${ }^{20}$ Forum Iudicum $^{21}$ and Liber Iudiciorum. ${ }^{22}$

Regarding the Langobardic law material it should be noted that, contrary to most of the German folk laws that grouped rules in terms of subject, Langobardic laws sequenced legal rules in the chronological order of their rulers. ${ }^{23}$ In Langobardic laws - which were created with the assistance of a popular assembly ${ }^{24}$ - several German legal terms enriched the Latin text. Although the Langobards had already been in Italy for seventy-five years, their customary law was only recorded by King Rothari in 643. ${ }^{25}$ This code, the Edictus Rothari, was confirmed by him ${ }^{26}$ with the consent of his peers and the people in a symbolic form of contract (speergedinge per gairethinx). ${ }^{27}$ The Edictus Rothari consisted of short provisions, which can be understood with the help of Langobardic folk language terms. Contrary to Visigothic, Ostrogothic and Burgundian law material, the Edictus Rothari to a lesser extent shows a close relation with Roman law. ${ }^{28}$ We can agree with Babják ${ }^{29}$ that a part of the Edictus Rothari expressly contained old Longobardic customary law and that the remaining part summarised the king's legal reforms.

Alemannian folk law has been left to us in two versions: Among scholars the older version is generally referred to as the Pactus Alamannorum (hereafter Pactus) and the more recent one is known as the lex Alamannorum. The introductory sentence of the Pactus (left to us only fragmentary in one single manuscript) mentions King Chlothar from the Merovingian dynasty ${ }^{30}$ as lawmaker. Opinions in literature are, however, divided on whether this ruler refers to King Chlothar I (511-561), II (584-629) or IV (717-719). Most probably King Chlothar II was the author of the Pactus, because the language of this law is similar to that of the lex Ribuaria and the later versions of the lex Salica, whereas the lex Alamannorum may be attributed to Lantfrid's lawmaking activity. ${ }^{31}$ The authorship of King Chlothar II also seems to be supported by the fact that in September 626 or 627 forty bishops, one abbot and one deacon (the latter as agent) were also present at the Council of Clichy, and this number of participants showed a similar order of magnitude to the description

19 Nehlsen 1978: 1966-1979.

20 Conrad 1962: 59.

21 Tate 2004: 513.

22 Babják 2005: 19.

23 Brunner 1906: 530.

24 Schröder 1907: 255.

25 Zoepfl 1871: 70.

26 Brunner 1906: 531; Schröder 1907: 255.

27 Ebel \& Thielmann 2003: 126.

28 Lenel 1915: 392.

29 Babják 2005: 171.

30 Lex Alamannorum, Prologus.

31 Schott 1993: 16. 
provided in the Pactus. ${ }^{32}$ The lex Alamannorum makes it clear that compilers further developed the rules of the Pactus in content as well. ${ }^{33}$ This version was probably created sometime between 712 and 725 .

\section{Medicine and the physician in the early Middle Ages}

\section{Early medieval medicine}

In the early medieval art of therapeutics we can distinguish two main branches, namely (i) the medicine exercised at royal (ducal) courts and monasteries, considerably influenced by the ancient traditions of Hippocrates and Galenos and the reception of their texts, and (ii) folk medicine fundamentally based on oral tradition and related to German traditions. ${ }^{34}$

In the therapeutics of the period, the centres of the Mediterranean, more specifically that of the Byzantine Empire, were considered the best developed because ancient tradition had survived most strongly in Alexandria. From among the persons who mastered scholarly medicine the names of Oreibasiois ${ }^{35}$ Aetios of Amida ${ }^{36}$ Alexandros of Tralles and Paulus of Aigina ${ }^{37}$ should be highlighted, since they saved this body of knowledge by making abstracts of ancient works of medical science for the Middle Ages. ${ }^{38}$ Several of their compilations were translated into Latin quite early, and these Latin translations later constituted the basis of scholarly medicine in the western part of Europe. These works showed little originality compared to ancient sources and may mostly be considered as simplified abstracts of the ancient tradition. ${ }^{39}$ (Later, these compilations were also translated into Arabic and thus became the basis of Arabic medicine, which began to develop significantly from the eighth century and produced an impact from the eleventh century in southern Europe, primarily in Hispania and later also in southern Italy. ${ }^{40}$ )

Folk medicine was originally based on German religious concepts, and in time the effect of classical (ancient) therapeutics could be observed in this branch of medicine. For example, in Gaul medical prescription books were written as early as in the fifth and sixth centuries. Amongst these the work of Marcellus Empiricus is worth highlighting. ${ }^{41}$ However, the following prescription collections should also be

32 Fastrich \& Sutty 2001: 85.

33 Schott 1993: 12.

34 Niederhellmann 1981: 74.

35 Diepgen 1949: 164; Lichtenthaler 1974: 227.

36 Diepgen 1949: 164; Lichtenthaler 1974: 229.

37 Diepgen 1949: 165.

38 Benedek 1990: 71.

39 Niederhellmann 1983: 39.

40 Baader 1973: 275-296.

41 Niederhellmann 1981: 74; Sigerist 1923: 186. 
mentioned: the Codex Sangallensis ( $\mathrm{nr} 44)$ (containing scattered German terms) and the eighth/ninth century Codex Bambergensis. ${ }^{42}$ The Old English Leechbooks created from the ninth century onwards were considerably affected by the approach of folk medicine influenced by German religious concepts. ${ }^{43}$ As a result of the Catholic Church doctrine that tried to take firm action against such so-called heathen religious notions, it is hard to find any text in these sources that communicate exclusively German folk belief and folk medicine to us. ${ }^{44}$ Despite these notions magical rites survived in Christianised form in folk medicine and were included in prescription books. ${ }^{45}$

Church doctrine was greatly influenced by medical thinking and terminology, especially in the works of the early church fathers. For example, Tertullianus called baptismal water aqua medicinalis, that is "medicinal water" or "water restoring health". ${ }^{46}$ Other old Christian authors, such as Irnaerius, Ignatius and Iustinus referred to repentance as vera de satisfactione medicina and to the Eucharist as the pharmakon of immortality. ${ }^{47}$ In line with Christian dogma church medicine often considered to be the cause of disease, and so considered repentance as a kind of cure; the ecclesiastic person carrying out the healing imitating Christ as the Redeemer and physician of the soul. ${ }^{48}$ In contrast to early Christian thinking, a viewpoint less refusing of the body and its diseases became observable in the Catholic Church from the fourth to the fifth centuries. ${ }^{49}$

The scenes of so-called scientific healing - which was, first of all, based on the simplified teaching of Hippocrates and Galenos - were primarily monasteries where monks were provided with medical training within the framework of quadrivium..$^{50}$ As, in theory, the works of ancient medical science were available to these clerics, they often used a peculiar mixture of scientific and theurgical methods. In Vivarium in southern Italy - founded by Cassiodorus (485-580), the Chancellor of Theoderich - copies and translations of several works of ancient medical science were made. ${ }^{51}$ Isidorus Hispalensis (570-636) devoted two of the twenty books of Etymologiae to medicine. ${ }^{52}$ Walahfridus Strabo, who wrote his works at the monastery of Reichenau, in his instructive poem entitled De cultura hortorum consisting of four hundred and

Jörimann 1925: 5-77.

Rubin 1974: 43.

Hansen 1900: 36.

Cockayne 1965: vol 1 384, vol 3 286; Grendon 1909: 105-237; Brie 1906: 1-36; Eis 1964 passim. Harnack 1892: 132.

Lichtenthaler 1974: 269; Harnack 1892: 133.

Siebenthal 1950: 7; Diepgen 1922: 52; Schadewaldt 1964: 150; Arbesmann 1954: 1-28; Rothschuh 1978: 49.

Schadewaldt 1964: 150; Siebenthal 1950: 50; Harnack 1892: 65; Diepgen 1922: 7; Lichtenthaler 1974: 242; Niederhellmann 1983: 42.

Wolter 1976: 55; Diepgen 1958: 7; Niederhellmann 1981: 76.

Cassiodorus Institutiones 131 1; Diepgen 1922: 192.

Wolter 1976: 50. 
forty-four hexameters, wrote at length on the curative effect of twenty-three plants and the ground-plan of the latter monastery reveals that the building included an infirmarium consisting of a pharmacy as well as medical, patient and treatment rooms. ${ }^{53}$ Our sources on physicians who lived in non-ecclesiastical or rulers's courts - and who were sometimes granted the title comes archiatorum, that is "head physician" - are highly imperfect, and we know almost nothing of simple medici attending the common people. ${ }^{54}$ Physicians who attended the ruling class often made a fortune. However, if the treatment applied by them brought no result, inefficiency quite frequently cost them their lives. ${ }^{55}$ On the other hand, surgery was not included in scientific works of that period since it was literally considered to be kheir-ourgia, namely "handi-craft", and as such did not belong to the field of medicine considered as ars or scientia. ${ }^{56}$

\section{Legal status of physicians in the early Middle Ages}

Unfortunately the lex Baiuvariorum did not contain any reference to physicians' legal standing and social status. Nevertheless, physicians enjoyed great social prestige, as is clear from the Alemannian law when compared to the Bavarian lex. ${ }^{57}$ Accordingly, a physician, whose oath was worth as much as the oath of three laymen, had to take his oath on his medical instruments which symbolised his vocation and high position in society. The quoted text determined the process of deciding disputes concerning the conpositio to be paid for the injury caused; in other words, in this case the physician acted as an expert. ${ }^{58}$

The following Alemannian locus also informs us about the fact that the testimony of physicians was of greater weight than that of common people..$^{59}$ The source stated that if a physician had lost the piece of bone from the skull/calvarium that would serve as proof before court, the physician either had to take an oath that he had lost it, or two eyewitnesses had to take an oath that it was really a piece of bone that was "knocked out" of the calvarium when committing bodily injury - it is difficult to explain or identify the phrase medically. Here the therapeutist therefore acted also as an expert in court. We can only presume that becoming an expert was subject to complying with specific conditions, determined at least by customary law. In other words, a physician probably had to prove his expertise, as is clear from the Old Norse Manhoelingsbalker ${ }^{60}$ which stated that persons who proved that they

53 Niederhellmann 1983: 44.

54 Diepgen 1922: 199; Niederhellmann 1983: 45.

55 Baader 1979: 179.

56 MacKinney 1957: 395; Diepgen 1958: 16.

57 Pactus legis Alamannorum 12.

58 Niederhellmann 1983: 66.

59 Lex Alamannorum 575.

60 Reier 1976: 672. 
were able to heal wounds, bone fractures, injuries in the chest and abdomen caused by weapons, the stump of cut-off limbs and stab wounds could become "forensic medical experts". ${ }^{61}$

Visigothic law devoted an independent titulus to the regulation of the legal position of physicians and patients (De medicis et egrotis) ${ }^{62}$ which sufficiently proves the important social role of physicians. ${ }^{63}$ In Visigothic law, the relation between a physician and a patient was regulated by a contract guaranteeing mutual security (placitum) ${ }^{64}$ On the basis of the contract entered into between the physician and the patient, the physician was obliged to heal the patient - that is, quite peculiarly, the physician contracted for an obligation of result rather than an obligation of care - and the patient was obliged to pay the fee for healing by giving security (cautio) for it when concluding the contract. The law also regulated the case of unsuccessful treatment. ${ }^{65}$ If the patient died while being treated, that meant that the physician could not heal him or her, or, put differently, he was unable to fulfil his obligation assumed in the contract; as a result he could not lay claim to the fee agreed upon. The patient's family, however, could not lay a charge of homicide against the physician. ${ }^{66}$

However, to ensure the safety of the physician, Visigothic law provided the physician-patient relationship with further guarantees ${ }^{67}$ Accordingly, (also indicating physicians' high social standing) physicians could not be taken into custody without interrogation, except in the case of homicide. Here homicide referred to voluntary homicide and not exitus that could not be imputed to the physician - in this case he had to provide a guarantor to the value of the compositio to be paid for homicidium. The relationship between physicians and their students was also regulated by law. ${ }^{68}$ In return for training - carried out not in an organised form but in terms of an individually concluded contract within the framework of the master/student relationship based on personal trust - a physician could claim payment of twelve solidi from his student.

61 Niederhellmann 1983: 67.

62 Lex Visigothorum 11 1-8.

63 Niederhellmann 1983: 67.

64 Lex Visigothorum 1113.

65 Idem 1114.

66 Amundsen 1971: 559; Diepgen 1922: 198.

67 Lex Visigothorum 1118.

68 Idem 1117. 


\section{Regulation and terminology of diseases, miscarriage and injury in the lex Baiuvariorum}

\section{Diseases influencing legal capacity and capability of proceeding under the law in the lex Baiuvariorum}

How did the terms "patient" and "disease" appear in the Bavarian Volksrecht? As these were legal texts, diseases were mentioned only when they influenced a person's capability of participating in legal processes changing his legal status (specifically leprosy and mental illness) or when they had an effect on the person's capacity to work (such as blindness and hernia, namely an inguinal hernia). Before analysing loci of the lex Baiuvariorum, it is worth surveying the relevant passage of the Edictus Rothari which provided a broader view of social judgement and legal regulation of diseases influencing the capability of proceeding under the law and status than the Bavarian source.

According to the Edictus Rothari, the cause of mental illness should be looked for in $\sin .{ }^{69}$ The Edictus Rothari clearly fits in with the Christian tradition stating that mental illness is a consequence of sin - even if this thought was not alien to the notions of other religions. ${ }^{70}$ Although the basis of this thought cannot be found in either the Old or New Testament of the Bible, the church fathers derived it from a passage in the gospel according to John, where Christ warned people to avoid sin in order to avoid greater trouble. ${ }^{71}$ Congenital and hereditary diseases were attributed to original sin, and this notion was strangely mixed with a belief in demons at the time of early Christianity. ${ }^{72}$ Origenes connected specific illnesses with particular demons, whilst Augustinus, Tertullianus, Minucius Felix and Cyprianus formulated similar ideas. $^{73}$

Accordingly, the quoted locus of the Edictus Rothari called the patient a rabiosus or demoniacus. It should be added that in Middle Latin rabies denoted rabies spread by the bite of infected animals. ${ }^{74}$ This was mostly considered a synonym of hydrophobia ${ }^{75}$ which could be regarded as a typical symptom of rabies since a strong sense of thirst, accompanied by difficulties in swallowing and dread of fluids, appeared in the patient. ${ }^{76}$ Other symptoms of this illness included rage, somnipathy and foam at the mouth. However, in Langobardic texts "rabies" was set out arguably as

69 Edictus Rothari 323.

70 Rothschuh 1972: 3-17; Rothschuh 1978: 47.

71 Evangelium secundum Iohannem 514.

72 Siebenthal 1950: 43; Hempel 1965: 271; Harnack 1892: 133; Schadewaldt 1964: 151; Rothschuh 1978: 31.

73 Harnack 1892: 133; Niederhellmann 1983: 48.

74 Du Cange 1883-1887: vol 72.

75 Isidorus Etymologiae 4615.

76 Beek 1969: 124. 
the general name of all diseases involving fits of rage. ${ }^{77}$ The phrase demoniacus most certainly can be traced back to the notion that the patient was possessed by demons although, in Middle Latin this term (even if not as an exclusive phrase) was reserved for epilepsy, which is mentioned in the Hippocratic works as a sacred disease. ${ }^{78}$ Hippocratic doctrine, however, expounded that the opinion on the supernatural cause of this illness was untenable. ${ }^{79}$ At the same time, several sources gave evidence that in the Middle Ages epilepsy was no longer traced back to supernatural causes in every case, but that changes in the brain were suspected.

One of these sources is the lex Baiuvariorum which was recorded a century after the Edictus Rothari. It is worth quoting its locus - without discussing here its aspects of implied warranty - together with the glosses of the eleventh century manuscript marked by Gw. ${ }^{80}$ It is quite clear that in the twelfth century manuscript the glosses replaced the two phrases to be explained, namely that the term "hirniuuotic" must belong to "cadivus", that is, epileptic, and the term "holoht" should belong to herniosus, namely "person suffering from inguinal hernia". ${ }^{81}$ The etymology of the term "hirniuuotic" to be examined here is sufficiently clear: it was generated as the compositum of the Old High German and Middle High German phrase hirn(i) having the meaning "brain" and the Old High German wuotig and Middle High German wuotic - arising from the Indo-European root *uāt, *uōt-meaning "furious, raging". ${ }^{82}$ This phrase showed close relation with the Old Irish word "faith", meaning "seer", the Gothic word wōde, meaning "possessed" and the Old English word wōd, meaning "insane". ${ }^{83}$ This etymological reasoning makes it obvious that in case of epilepsy the cause of illness was presumed to be changes in the brain as nothing implied a supernatural cause in the term hirniunotic. ${ }^{84}$

The provision of the Edictus Rothari unambiguously stated that the capacity to participate in the legal processes of persons suffering from this illness was limited: they lacked criminal capacity. As a result, culpability lacked in damages caused by rabiosus and demoniacus, and crimes committed by them shall not be punished, meaning that they did not have to pay compositio usually required. The patient's relatives could not be held responsible for their acts and no compensation could be claimed from them. At the same time, the relatives could not claim compositio if somebody killed the patient by negligence (sine culpa). In other words, the

77 Niederhellmann 1983: 49.

78 Du Cange 1883-1887: vol 3 2; Niederhellmann 1983: 49.

79 Beek 1969: 85.

80 Lex Baiuvariorum 16 9: id est aut cecum aut herniosum ( $G w$. hoc est hirniunotic) aut cadicum ( $G w$. cativo id est holoht) aut leprosum.

81 Schade 1882: vol 1 414; Niederhellmann 1983: 50.

82 Schade 1882: vol 1 402, vol 2 1216; Lexer 1872-1878: vol 2 1303, vol 3 385; Pokorny 1959: vol 11113.

83 Pokorny 1959: vol 11113.

84 Niederhellmann 1983: 51. 
patient was governed by the same rules that exempted the keeper of an animal from compensation for damages caused by a rabid animal and deprived him from the right to claim compensation. ${ }^{85}$ (With regard to mentally retarded and insane persons, the Visigothic law applied the rule of Roman law: only statements made in their own cases and during possible periods of their lucida intervalla were valid, otherwise their manifestations of will were invalid. Furthermore they could not act as witnesses in court, and if they had nevertheless furnished evidence, their testimony could not be taken into account. ${ }^{86}$ ) According to the Edictus Rothari, when a buyer noticed after having entered into a contract of purchase and sale - that the slave was a leper or an epileptic, he could reclaim the purchase price while returning the slave; the seller could defend by a cleansing oath that he had not known of the slave's illness at the time of delivery. ${ }^{87}$ This provision was basically in line with the above-quoted Bavarian passage which in turn was most probably influenced by the Langobardic law. ${ }^{88}$

Pursuant to the Edictus Rothari, a concluded engagement could be contested, in other words, the fiancé could reclaim the wedding present and could not be obliged to enter into marriage if it appeared later that the fiancée was a leper, blind in both eyes or an epileptic. ${ }^{89}$ In addition to the above two cases (purchase and sale and contesting an engagement), in the case of leprosy, the law also linked further legal consequences to concealing the illnesses. ${ }^{90}$ The law considered leprous patients to be legally dead and expelled them from the community. If the fact of the illness was unambiguously proved to the judge and the people, the patient had to leave his house in the city and had to live alone outside the community; he could not sell or pledge his assets; he lost his right of inheritance; and could not use legal assistance. At the same time, the relatives were obliged to care for the outcast from the assets left behind by him. This latter provision was not free from contradiction since the lawmaker imposed on the bereaved the obligation to care for a de jure dead person. The only novelty in Langobardic legislation was that it qualified the leprous patient as dead and a legal outcast since persons suffering from this infectious, incurable disease involving frightening symptoms had already de facto been separated in antiquity. ${ }^{91}$ Nevertheless, the question now is what illnesses were considered as leprosy in early medieval sources? Most probably not only illnesses that can be diagnosed as leprosy today (although modern medical science describes three types of it), but also numerous other skin diseases, including, for example, certain kinds of psoriasis or pellagra.

85 Edictus Rothari 324.

86 Lex Visigothorum 2511.

87 Edictus Rothari 230.

88 Dilcher 1978: 1611.

89 Edictus Rothari 180.

90 Idem 176.

91 Singer 1928: 86; Niederhellmann 1983: 55. 
The viewpoint of the Church played an important part in the legal judgement of leprosy. On the one hand it was of the view that several loci in the Bible proved that leprosy was a punishment inflicted for breaching divine law, and further instructed people to expel the patient from the community. ${ }^{92}$ On the other hand, the Church strove to care for lepers. For example, Gregorius Turonensis asserted that bishop Agricola of Châlon (535-580) set up an exsinodochium leprososrum outside the city; ${ }^{93}$ the Fifth Council of Orleans in 549 obliged bishops to care for lepers $;{ }^{94}$ and the Third Council of Lyon in 583 imposed the obligation on bishops to comply with the provision that forbade lepers to go to the territory of other bishoprics in order to prevent the illness from spreading. ${ }^{95}$ (It may be deduced from this latter source that lepers wandered about in groups in the province to beg for money and food necessary for subsistence. ${ }^{96}$ ) The biography written by Walahfridus Strabo, abbot of Reichenau, on Otmar, the abbot of St Gallen, states that Otmar had set up a hospitium for lepers not far from the monastery but outside its walls. ${ }^{97}$ However, since leprosy was incurable in those days, the purpose of this institute most probably was the separation of patients only and it is unlikely that any healing was done there. ${ }^{98}$ The prohibition against lepers wandering around could not have been effective since Charlemagne ordered in his edictum of 789 that lepers should be separated. ${ }^{99}$ Although efforts were taken to separate lepers and expel them from the community even prior to Langobardic legislation, the Edictus Rothari was the first legal source that enacted their separation and de jure death. ${ }^{100}$

\section{Aspects of abortion in the lex Baiuvariorum}

With regard to the crime of abortion the lex Baiuvariorum provided as follows: If a female slave administered medicine that served or caused a pregnant woman to abort, she would be whipped two hundred times, and if the perpetrator was a woman in free status, she would lose her freedom and would become the slave of the person to whom the duke assigned her. ${ }^{101}$ Compared to the rules of the lex Visigothorum (discussed below) it becomes clear that whereas Visigothic law involved the pregnant woman in the scope of perpetrators and provided that the person who administered or delivered the medicine could be a man or a woman, Bavarian law did not state whether the woman taking the medicine was required to have intended to cause

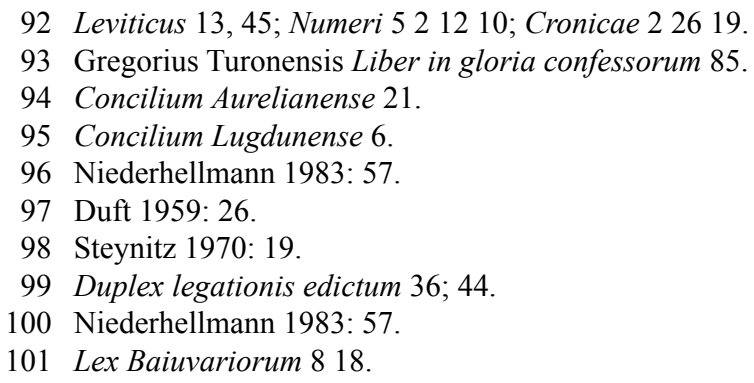


abortion or was merely unaware of the effect of the medicine taken or administered. The similarity of the sanction - namely being whipped two hundred times and the loss of free status - and the punishment differentiated in terms of personal status allow us to regard it as probable that the two laws may be traced back to the same source, namely the Codex Euricianus. ${ }^{102}$

Killing a pregnant woman by beating was punished by death in terms of the lex Baiuvariorum. However, if only the foetus died, the perpetrator had to pay twenty solidi conpositio, but if the foetus had already "lived", in other words if pregnancy had reached a more developed stage, the conpositio rose to one hundred and sixty solidi. ${ }^{103}$ Visigothic law required payment of one hundred solidi conpositio in the case of causing death of the foetus and one hundred and fifty solidi conpositio in the case of causing the death of a foetus that "has assumed human form". ${ }^{104}$ It may be deduced from the sanction differentiated in accordance with the development of the foetus that in this case the source of both laws had again been the Codex Euricianus. ${ }^{105}$

The viewpoint of the Church is reflected in two passages in the lex Baiuvariorum. ${ }^{106}$ In the case of abortion, in addition to conpositio to be paid in one amount, the perpetrator and his descendants were obliged to pay one solidus annually to the seventh generation. The law justified this highly stringent rule by stating that the soul deprived of the possibility of birth also "suffers long-lasting punishment" since it descended to hell without the sacrament of baptism. It is remarkable that this passage begins with the same words as another passage preceding it, where the same facts and sanction were discussed. It is absolutely clear that whereas the other abortionrelated loci in the lex Baiuvariorum reflects the German legal approach, these two show the impact of Christianity, which proves - when analysed with regard to the creation and editing of the lex Baiuvariorum - the joint existence of different layers of the text. ${ }^{107}$

The crime of abortion carried out by a woman on herself and abortion carried out at the woman's request cannot be found in Frisian, Salian Frankish, Ripuarian Frankish and Langobardic law or in the Pactus legis Alamannorum. ${ }^{108}$ The Saxon, Thuringian and Burgundian law do not discuss abortion in any form whatsoever, that is, they do not even consider the case where abortion is caused by a violent act of the perpetrator as an independent crime. This suggests that, in contrast to the Frisian, Salian Frankish, Ripuarian Frankish and Langobardic laws as well as the Pactus legis Alamannorum, where abortion carried out by somebody else at the woman's request

102 Fastrich-Sutty 2001: 161.

103 Lex Baiuvariorum 819.

104 Lex Visigothorum 632.

105 Fastrich-Sutty 2001: 161.

106 Lex Baiuvariorum 8 20-21.

107 Schwind 1908: 634; Morsak 1977: 201; Niederhellmann 1983: 137.

108 Niederhellmann 1983: 129. 
or by the woman herself, these peoples (under ecclesiastical influence) considered any form of killing of the foetus as homicide and sanctioned it as such. ${ }^{109}$

Visigothic law, greatly influenced by Christian doctrine, discussed the issue of abortion/pregnancy at length under the title De excutientibus hominum partum. ${ }^{110} \mathrm{First}$, the law regulated abortion carried out by an abortive drug. ${ }^{111}$ When the punishment of the person who had administered/delivered the abortive drug was dead and it was the woman who had requested an abortive drug and the administration thereof, the regulation included the woman as a perpetrator: If she was a slave, her punishment was to be whipped two hundred times and if she was a person of free status, she lost her freedom. Furthermore, the law determined the sanction for miscarriage caused by a free man assaulting a pregnant woman of free status. ${ }^{112}$ Accordingly, if a free man had caused a miscarriage by assaulting a free woman and the woman died, he would be punished on the basis of homicide; however, in the case of causing the death of the foetus only, one hundred, and in case of a foetus that "had assumed human form" one hundred and fifty solidi conpositio were to be paid.

In these provisions, German and Roman law elements are intermingled in an interesting form since amounts of conpositio may be traced back to the impact of the German law elements, whereas other punishments, such as whipping, the death sentence or loss of free status, may be tracked back to Roman law elements. ${ }^{113} \mathrm{It}$ is worth mentioning that the sanction for miscarriage caused by an abortive drug was more stringent than the sanction for miscarriage caused by bodily injury; the reason for this may probably be found in the fact that abortive drugs were classified as "magic potions" and that medicines of magic were considered to be highly dangerous. ${ }^{114}$ This seems to be supported by the fact that even Burchard of Worms viewed the interruption of pregnancy by abortive drugs as witchcraft. ${ }^{115}$ This viewpoint somewhat corresponds to the Roman law regulation that punished the use of abortive drugs similarly to the use of aphrodisiacs. ${ }^{116}$ The oldest layer of Visigothic regulations most probably borrowed from Sulla's regulations ${ }^{117}$ which did not punish the woman who had carried out an abortion on herself, but punished the person who had administered the abortive drug. ${ }^{118}$ (Roman law sanctioned abortion only from the period of the Severi. Women were punished not simply for killing the foetus, but also for depriving the father from a child who would be under his power

109 Idem 130.

110 Lex Visigothorum 63 1-7.

111 Idem 631.

112 Idem 632.

113 Nehlsen 1978: 1976; Nehlsen 1972: 233.

114 Niederhellmann 1983: 131.

115 Burchardus Vormatiensis Decreta 972.

116 Paul D 4819385.

117 D $25411 ; 35291$.

118 Nehlsen 1972: 234. 
in the future - this is illustrated by the fact that only married and divorced women were threatened by this sanction, whilst unmarried mothers were not. ${ }^{119}$ We may presume that the mentality of Visigothic regulations was rooted in canon law rather than in Roman law. ${ }^{120}$ ) King Chindasvint made the sanctions for abortion even more stringent. ${ }^{121} \mathrm{He}$ regarded abortion and attempted abortion as a crime against pietas and ordered perpetrators to be punished by death or blinding, even in the case where a woman did it with the consent of or on the orders of her husband - in the latter case, the husband was to be punished as well.

The lex Alamannorum determined the sanction for abortion according to the gender of the foetus. ${ }^{122}$ The conpositio of a foetus showing female attributes was double that of the conpositio of a male foetus; however, if it was not yet possible to determine its gender, that is if the human form had not yet developed, the required conpositio was similar to that of the male foetus.

It is clear that the leges differentiated in determining the rate of conpositio for causing miscarriage in terms of the gender of the foetus and - as the provisions of the lex Visigothorum and the lex Baiuvariorum show - the stage of development and whether the foetus was alive. This differentiation may be traced back to several ancient and early Christian authors. Aristotle dated commencement of the motion of a male foetus to the fortieth day, and of the female foetus to the ninetieth day after conception. Following the Hippocratic tradition, which Galénos joined as well, a male foetus assumed its human form after the third month and a female foetus only after the fourth month. ${ }^{123}$ Contrary to the views of antiquity, Christian tradition took the date of the soul moving in rather than the date of assuming human form as the basis of its stance on abortion. This tradition can be traced back to an erroneous Septuaginta translation of a locus of the book of Exodus, ${ }^{124}$ which speaks about the soul moving into the body of the foetus, and was not included in the Vulgata translation, but - influenced by the thoughts of Aristotle and Hippocrates - returned repeatedly in the works of the church fathers. The basic question concerned which date following conception abortion was to be considered homicide. Quite interestingly, certain councils did not pay regard to the issue of the date at all. ${ }^{125}$ However, certain authoritative authors such as Augustinus and Hieronymus considered abortion to be homicide only from a given point of time. They argued that the soul could only move into the body once the body reached a certain level of development; they did not view abortion before this level of development as homicide. ${ }^{126}$

119 D 4711 4; 48 8 3; 48 8 8; 48 19 39. See, also, Morsak 1977: 202.

120 Niederhellmann 1983: 132.

121 Lex Visigothorum 637.

122 Lex Alamannorum 88 1-2.

123 Niederhellmann 1983: 134.

124 Exodus 21 22-23.

125 Lex Visigothorum 637.

126 Niederhellmann 1983: 135. 


\section{Involvement of the physician and treatment in the lex Baiuvariorum}

Although folk laws determined different conpositio for various forms of bodily injury, they set conpositio for certain injuries, although subject to the need for and the type of medical help. When involvement of the physician was necessary, the lex Baiuvariorum raised the amount of conpositio to one and a half solidi if hitting or stabbing resulted in the injuring of a vein or exposing the bone of the skull. ${ }^{127}$ The regulation of the Edictus Rothari usually made it possible to claim the physician's fee, in addition to the amount of conpositio, from the perpetrator. ${ }^{128}$ Furthermore, a general rule pronounced that the perpetrator was obliged to arrange for a physician for the injured party - failing which, the injured party or, in the case of slaves, their owner could call a doctor - and pay his fee as determined by experts. ${ }^{129}$

We may learn much about surgical treatment applied in the case of skull injuries from two passages of the lex Alamannorum. One of the loci described the case where the brain became visible as a result of skull injury. ${ }^{130}$ Regarding its treatment the text described that the physician touched the brain with an instrument called pinn(a) or fano(ne). In terms of the history of language, the word pinn declined in a Latin form may probably be related to the Old English word pinn, meaning "small piece of wood/metal ending in a cylinder"; to the Old High German and Middle High German word pin(ne), meaning "little arrow"; or possibly to the Latin word penna, meaning stalk (of straw) or to the Middle Latin word pen, meaning "arrow stem" Anyway, it denoted a pointed probelike instrument, ${ }^{131}$ which was also suitable for removing bone chips. The term fano indicates a relation to the Old High German and Old Saxon word fano as well as the Anglo-Saxon and Gothic word fana meaning "scarf", ${ }^{132}$ and it probably denoted the bandage put on the wounds. ${ }^{133}$

The other locus discussed the case where the cerebrum became not only visible, but partly protruded from the skull cavity. ${ }^{134}$ Medical intervention, namely placing

127 Lex Baiuvariorum 5 3: Si manus inicerit et ita plagaverit, ut medicum inquirat, vel si venam percusserit. Si in eum contra legem manus iniecerit, quod infanc dicitur, vel si in eum plagaverit, ut propter hoc medicum inquirat, vel sic ut in capite testa appareat vel vena percussa fuerit, cum solido et semi conponat.

128 Edictus Rothari 78-79; 82-84; 87; 89; 94; 96; 101-103; 107; 110-112; 118; 125.

129 Edictus Rothari 128: De eo qui plagas fecerit, ipse querat medicus, et si neclexerit, tunc ille qui plagatus est aut dominus eius inveniat medicum. Et ille qui caput rumpit aut suprascriptas plagas fecit, et operas reddat et mercedes medici persolvat, quantum per doctos homines arbitratum fuerit.

130 Lex Alamannorum 57 (59) 6: Si autem testa (id est kebul) transcapulata fuerit, ita ut cervella appareat, ut medicus cum pinna aut cum fanone cervella tetigit, cum XII solidis conponat.

131 Pokorny 1959: vol 1 97; 830; Du Cange 1883-1887: vol 5 327; vol 6257.

132 Kluge 1899: 180; Schützeichel 1974: 47; Schade 1882: vol 1160.

133 Niederhellmann 1983: 78.

134 Lex Alamannorum 57 (59) 7: Si autem ex ipsa plaga cervella exierit, sicut solet contingere, ut medicus cum medicamento aut sirico stupavit (id est virscoppot), et postea sanavit, et hoc probatum fuerit, quod verum est, cum XL solidis conponat. 
the brain back into the skull cavity was denoted by the word virscoppot in the text. Etymologically, this phrase may be explained as follows: The Old High German verb stopfön/scoppon means "patching"; 135 the prefix is related to the Old High German prefix far-, fir- ( $c f$ New High German ver-) and the suffix -ot added to verbs ending in $\bar{o}$ making the phrase a noun. ${ }^{136}$ The circumstances of the intervention described in folk language by the text makes it probable that it was applied not only by physicians who studied at monasteries and pursued medicine on a scientific basis, but also by people who practised folk medicine. In the text, siricum, meaning "silk", was used for the sewing up of wounds, and was used in Old Norse therapeutics (silkiprcedi) for this purpose. ${ }^{137}$ The Old English Leechbooks provided more extensive information on how to carry out the operation, such as what material the support bandage should be made of and how bone chips may be successfully removed from the brain. ${ }^{138}$ The interventions described here and similar ones have been proved by archaeological finds, like the graves explored in Allach, Chamünster, Greding and Aidenbach. From these finds it may be deduced that in certain cases the operation was performed successfully since fractures of the skull were found to have healed apparently as a result of a medical intervention. ${ }^{139}$

Cauterisatio, meaning "burning of the wound" and thus closing of the veins in order to stop bleeding, is evident from a locus in the lex Baiuvariorum. ${ }^{140}$ The lex Alamannorum also contains two passages on a similar procedure. ${ }^{141}$ In the text of the lex Alamannorum, the folk language phrase $z i$ virstreddene may be connected with the Old High German verb stredan meaning "to glow" or "to become hot" - the gloss attached to the Alemannian law already shows signs of the Middle High German "Lautverschiebung" 142 - and is used as the gloss for fervere in the Murbach Hymns, which were also, like the lex Alamannorum, recorded on the Isle of Reichenau. ${ }^{143}$ The form used here is a praesens participium, to which the above-mentioned Old High German praefixum vir- ( $c f$ New High German ver-) was added, ${ }^{144}$ and was preceded by the praepositio zi ( $c f$ New High German $z u$ ), and could therefore be rendered

135 Kluge 1899: 753; Schade 1882: vol 2875.

136 Niederhellmann 1983: 79.

137 Reier 1976: 592; Rubin 1974: 137.

138 Cockayne 1965: vol 2114.

139 Niederhellmann 1983: 80.

140 Lex Baiuvariorum 4 4: Si in eum vena percusserit, ut sine igne stangnare non possit, quod adarcrati dicunt, vel in capite testa appareant, quod kepolsceni vocant, et si ossa fregit et pelle non fregit, quod palcprust dicunt, et si talis plaga ei fuerit, quod tumens sit: si aliquid de istis contigerit, cum VI solidis conponat.

141 Lex Alamannorum 65 5-6: Si manum transpunxerit, ita ut focus non intret ad coquendum venae vel sanguinem stagnandum id est zi virstrddene, solidum unum et semmis conponat. Si autem ferrum calidum intraverit ad stagnandum sanguinem, cum III solidis conponat.

142 Lexer 1872-1878: vol 21229.

143 Schmidt-Wiegand 1978: 31; Schützeichel 1974: 185.

144 Schützeichel 1974: 246. 
most aptly by the translation zu verglühende. ${ }^{145}$ Burning the wound to stop bleeding had been a basic duty of a surgeon since antiquity, and it is not by chance that the phrase cauterio aut ferro is included as a closely related term in the text of the Council of Châlon in 813. ${ }^{146}$ The Old English Leechbooks and the Old Norse sagas reveal that burning was also used to remove a tumor growing out of the wound after the operation. ${ }^{147}$

\section{German terminology of injury in the lex Baiuvariorum}

As the terminus technicus used by the Bavarian lex for various forms of bodily injury and injuries is always defined in folk language as well, we shall discuss these phrases below.

The word hrevavunt occurs three times in the text of the lex Baiuvariorum. ${ }^{148}$ The lex Alamannorum uses the term hrevovunt to denote (probably less serious ${ }^{149}$ ) injuries to internal organs. ${ }^{150}$ In contrast, the lex Baiuvariorum uses the phrase hrevavunt not only for injuries to internal organs, but also for head injuries where the brain was exposed and for bodily injuries leaving the injured party in a halfdead state. The lex Baiuvariorum imposes the same compositio as for hrevavunt in the narrower sense in accordance with the Alemannian law. ${ }^{151}$ Etymologically, the first morpheme does not derive from the Old High German word hrêo, namely "dead body" (cadaver), but instead is related to the Old High German word href or ref, the Anglo-Saxon word hrif and the Old Frisian word (med)ref meaning "body" or "lower parts of the body", ${ }^{152}$ which are etymologically related to the Latin word corpus. ${ }^{153}$ It is possible to draw this conclusion from copying errors of certain manuscripts. Some of the medieval copiers associated the Bavarian phrase with the word cadaver, as implied by the Middle High German phrase ferchwunt (todtund). ${ }^{154}$ The error might have occurred because they transcribed the last letter of the Old High German href with an "u" or "v". ${ }^{155}$ Similarly, in certain manuscripts the way of writing of refvunt and refauunt clearly shows the proper etymology of the word since interiora membra in the text may be taken as the equivalent of the meaning

145 Niederhellmann 1983: 82.

146 Concilium Cabillonense 280.

147 Rubin 1974: 133; Cockayne 1965: vol 21 \& 35.

148 Lex Baiuvariorum 4 6: Si cervella in capite appareat, vel in interiora membra plagatus fuerit, quod hrevavunt dicunt ...; and 5565 .

149 Niederhellmann 1983: 247.

150 Lex Alamannorum 57 55: Si autem interiora membra vulneratus fuerit, quod hrevovunt dicunt, cum XII solidis conponat.

151 Niederhellmann 1983: 248.

152 Du Cange 1883-1887: vol 4 256; Graff 1834-1842: vol 41153.

153 Walde \& Hofmann 1954: vol 1194.

154 Lexer 1872-1878: vol 389.

155 Kralik 1913: 87. 
of the word href (corpus) rather than that of hrêo (cadaver). ${ }^{156}$ It is worth comparing the relevant loci of the lex Baiuvariorum with the loci of the Pactus Alamannorum where the word revo was used in the text, in addition to latus (meaning "side"), when referring to placatus in revo (meaning "internal part" in the sense of "injury to internal organs"). ${ }^{157}$ Here placatus in revo cannot mean "mortal injury" related to the word hrêo as its etymological base since the amount to be paid for it should be much higher. The second morpheme of the word, namely vunt (uunt) should be interpreted as participium, that is, in the sense of being "injured in his internal parts" ${ }^{158}$ The word hrevavunti is closely related to this phrase, which also occurs three times in the legal text. ${ }^{159}$ Contrary to the above-mentioned form, hrevavunti is the dativus of the feminine noun, its formation corresponding to the name of several scenarios in the lex Baiuvariorum (cf lidiscarti, adarcrati); in other words, it denoted "injury to internal parts". ${ }^{160}$

The term lidiscart(i) appears in the lex Baiuvariorum in connection with the cutting off of the ear as mutilation, distorting the outward appearance. ${ }^{161}$ The lex Alamannorum uses the phrase (or)scardi with regard to cutting off one of the ears. ${ }^{162}$ The regulations of the Bavarian lex differentiate varieties of injuries caused to the ears: It imposes different conpositio for piercing the ear and cutting off the auricle of the ear and for where the latter injury resulted in complete deafness. ${ }^{163}$ Lidiscart(i) is typically a South-German legal term ${ }^{164}$ which occurred in the Middle High German period in numerous legal texts in the form lideschart, liderscharte or lideschertic, meaning "to partially mutilate". ${ }^{165}$ Etymologically, the first morpheme of the phrase is connected with the Old High German noun gilid, the Old English lip, the Gothic lipus and the Indo-European root *elēi, *lēi, meaning "member" or "part of the body". ${ }^{166}$ The second morpheme of the compound is related to the Middle High German verb schart(e), the Old English sceard and the Old Norse skard, meaning "to cut" or "to hit. The latter derived from the Indo-European root $*(s) k r \bar{e}$ where the word-form itself was created by the formative $-i$ affixed to the relevant adjective ( $c f$ Old High German scart, Middle High German schart, Old English sceard). ${ }^{167}$ Regarding the phrase lidiscarti, it is possible to clearly describe how the word originally denoting

156 Idem 88.

157 Pactus Alamannorum 11: Si quis in revo placatus fuerit aut in latus; and 12: Si quis in latus alium transpunxerit, sic ut in revo placatus non sit.

158 Kralik 1913: 88.

159 Lex Baiuvariorum 16: Et quanti homines ibi intus fuerint et inlaesi de incendio evaserint, unique cum sua 'hrevavunti' conponat; and 1014.

160 Kralik 1913: 89.

161 Lex Baiuvariorum 4 14: Si aurem maculaverit, ut exinde turpis appareat, quod lidiscart vocant.

162 Lex Almannorum 57 10: Si enim medietatem auri absciderit quod (or)scardi Alamanni dicunt.

163 Lex Baiuvariorum 414.

164 Kralik 1913: 89.

165 Lexer 1872-1878: vol 1 1901; His 1920: 112.

166 Kluge 1899: 261; Pokorny 1959: vol 1307.

167 Kluge 1899: 637, 643; Bosworth \& Toller 1972: 824; Lexer 1872-1878: vol 2 709; Vries 1962: 490. 
wounding/damage to health became a legal term. An abstraction was created from the adjective developed from the participium praeteritum of the verb denoting the conduct of committing the act in order to name the injury, which served to determine conpositio more accurately in legal texts. ${ }^{168}$

In the lex Baiuvariorum, marchzand appears as the synonym of dens maxillaris, that is "jaw tooth", and refers to a molar. ${ }^{169}$ It is referred to in the lex Alamannorum where it has the same meaning. ${ }^{170}$ In both leges this is the only tooth that is also named in folk language, and this may be attributed to the fact that, in comparison to other teeth, a higher amount of conpositio had to be paid as compensation for knocking it out or breaking it off. Two explanations present themselves for the etymology of the first morpheme of the word. The first one asserts that the morpheme marc $(h)$ is related to the Old High German word mar $(a) g$, the Middle High German marc, the Anglo-Saxon marg, the German *mazga and the Indo-European *moz-g-o, *moz-gen and *mos-k-o, meaning "(bone) marrow" ${ }^{171}$ According to the other etymology, the word $\operatorname{marc}(h) a$, meaning "border" appears in this word. ${ }^{172}$ It should be noted that $\operatorname{marc}(h) a$ is actually not a medical term, but a legal or political one. The second morpheme of the word, zand, meaning "tooth" is a generally-used word in German languages and it is the praesens participium of the Indo-European root *ed, meaning "to eat" - the Indo-European forms *(e)dont and *dnt appears in the form zand in Old High German; tand in Old Saxon and New Dutch; tôth in Old Frisian; top in Old English; and zan in Middle High German. ${ }^{173}$ So marc(h)zand, in literal translation, means "border tooth" or "corner tooth, ${ }^{174}$ which corresponds with the Middle High German phrase marczan meaning "grinding tooth". ${ }^{175}$

Palcprust means a "fracture of bone" that is not open and where the bone end does not injure or pierce the skin. ${ }^{176}$ The locus shows a remarkable connection with the lex Alamannorum. ${ }^{177}$ In the interpretation of the first morpheme of the phrase it is essential to take account of the Old High German word balg, meaning "skin", the Gothic word balgs and the Old English word belg, meaning "leather case". ${ }^{178}$ The second morpheme is related to the Old High German phrase brust, meaning

168 Niederhellmann 1983: 285.

169 Lex Baiuvariorum 4 16: Si quis alicui dentem maxillarem, quod marchzand vocant, excusserit; and 610.

170 Lex Alamannorum 67 22: Si autem dentem absciderit, quod marczan dicunt Alamanni.

171 Kluge 1899: 462; Pokorny 1959: vol 1 750; Schmidt-Wiegand 1978: 25; Baesecke 1935: 18.

172 Graff 1834-1842: vol 5 683; Kralik 1913: 92.

173 Kluge 1899: 872; Pokorny 1959: vol 1 287; Niederhellmann 1983: 166.

174 Graff 1834-1842: vol 5 683; Kralik 1913: 92.

175 Lexer 1872-1878: vol 12044.

176 Lex Baiuvariorum 4 4: et si ossa fregit et pelle non fregit, quod palcprust dicunt, et si talis plaga ei fuerit, quod tumens sit.

177 Lex Alamannorum 67: Si enim brachium fregerit, ita ut pellem non rumpit, quod Alamanni balcbrust ante cubitum dicunt.

178 Pokorny 1959: vol 1 125; Schützeichel 1974: 12; Schade 1882: vol 2 37; Kluge 1899: 46; SchmidtWiegand 1978: 27. 
"fracture, scission"; 179 the Old High German and Old Saxon verbs brestan, the Old Norse bresta and the Old English berstan all meaning "to break, to tear up" as well as the Old High German noun bresti and the Old English byrst, meaning "damage", ${ }_{180}$ which derived from the Indo-European root *bhres and have also survived in the New High German verb bersten. ${ }^{181}$ Nevertheless, it is remarkable that palcprust simply means "skin injury" (Latin: pellis fractio), whereas the Latin text specifically states that it refers to a fracture of bone that has occurred during the injury, but where the bone has not pierced the skin - in other words, not an open fracture. The locus shows an interesting analogy in its reference to hraopant: ${ }^{182}$ in both cases the German terminus technicus accompanies the negation of the given state of facts. All this makes it probable that the Bavarians and the Alemanns defined an independent state of facts, namely a palcprust/balcbrust, which is further supported by the mention of expressis verbis in the lex Visigothorum, ${ }^{183}$ albeit without including the folk language name of the injury. The symptoms of the injury showing capillary rupture (libor, tumor etc) can be found in the Edictus Rothari too. ${ }^{184}$ However, as the locus is somewhat confusing and difficult to interpret, it can be argued that the phrase palcprust belonged to the ancient layer of German law passed on orally and that, as a result, this passage of the lex Baiuvariorum makes a former (more archaic) formulation appear in the final version left to us. ${ }^{185}$

In the lex Baiuvariorum the word pulislac denotes the scenario where somebody hits a free man out of anger or sudden passion (here the cause or motivation of the blow is not important with respect to the content of the folk language phrase), but where the injury does not result in an open wound (the latter denoted by plotruns). ${ }^{186}$ This phrase is also found in the lex Alamannorum where it has an identical meaning. ${ }^{187}$ In the lex Ribuaria it occurs in the form bulislege where it is mentioned in the context of abusing a slave; however, in this case the hitting does not cause bleeding. ${ }^{188}$ In the Edictus Rothari the phrase also denotes the hitting of a slave, but there a wound results from it. ${ }^{189}$ Etymologically, the first morpheme of the phrase may be related to

179 Graff 1834-1842: vol 3 106, 275.

180 Schützeichel 1974: 21; Kluge 1899: 68; Pokorny 1959: vol 1 169; Bosworth \& Toller 1972: 89.

181 Pokorny 1959: vol 1 169; Kluge 1899: 68.

182 Lex Baiuvariorum 48.

183 Lex Visigothorum 64 1: Si quis ingenuum quolibet hictu in capite percusserit, pro libore det solidos $\mathrm{V}$, pro cute rupta solidos $\mathrm{X}$, pro plaga usque ad ossum solidos $\mathrm{XX}$, pro osso fracto solidos C.

184 Edictus Rothari 46: ut cutica tantum rumpatur, quod capilli cooperint.

185 Schmidt-Wiegand 1978: 27.

186 Lex Baiuvariorum 4 1: Si quis liberum per iram percusserit, quod pulislac vocant; and 51.

187 Lex Alamannorum 67: Si quis alium per iram percusserit, quod Alamanni pulislac vocant.

188 Lex Ribuaria 19: Si ingenuus servum ictu percusserit ut sanguis non exeat usque ternos colpos, quod nos dicimus bunislege.

189 Edictus Rothari 125: Si quis servum alienum rusticanum percusserit pro unam feritam, id est pulslahi, si vulnus aut libor apparuerit. 
the Old High German words puilla and pulla ${ }^{190}$ the Middle High German biule, the Old English bŷle, the Old Saxon bülia, the Old Frisian bèl, bèle, beil and the IndoEuropean root $* b(h)(e) u$, meaning "swelling". ${ }^{191}$ The second morpheme of the phrase is associated with the Old High German word slac, the Old Saxon noun slegi, the Anglo-Saxon slag $(r)$ and the Gothic slahs, meaning "blow", which derived from the relevant verbs (the Old High German slahan, the Old Saxon slean, the Gothic slahan, the Old Frisian slagia and the Indo-European * slak). ${ }^{192}$ In Middle High German the word occurs in the form bûlslac, both in legal and non-legal sources. ${ }^{193}$ The injury may be defined as a blow which does not cause the handicaps or - as a general rule - bleeding, but results in swelling (cf Beulenschlag). ${ }^{194}$

The phrase taudregil (taudragil) occurs twice in the lex Baiuvariorum. In the first locus it is accompanied by a Latin explanation, namely a form of gait defect caused by bodily injury when the relevant person's "foot touches dew", meaning where "he drags his foot". ${ }^{195}$ This phrase in the same sense and with the same explanation is also found in the lex Alamannorum. ${ }^{196}$ The etymology of the first morpheme of the word is quite clear: it is connected with the Old High German word tau, meaning "dew". ${ }^{197}$ As pointed out by Grimm, the morpheme dregil/dragil may be related to the Gothic verb pragian, meaning "to run", as it has been pointed out by Grimm already. ${ }^{198}$ However, the analysed phrase most probably contains a more ancient meaning of the verb, more closely related to the German root *prag *prêg'199: "to drag" (trahere). ${ }^{200}$

The phrase adarcrati is accompanied by "dicunt" as predicate without the subject Baiuvarii, but it is quite certain that it is a Bavarian phrase. ${ }^{201}$ The locus refers to an injury (stabbing, cutting) to the vein where bleeding may be stopped only by burning. ${ }^{202}$ The first morpheme of the phrase may be connected with the Old High German word $\bar{a} d(a) r a$ or adar, the Middle High German a $d e r(e)$, the Old English cedre, the Old Norse ceđr and the Indo-European root *eter, meaning "vein"

190 Graff 1834-1842: vol 396.

191 Kluge 1899: 71; Pokorny 1959: vol 1 98; Schade 1882: 90; Bosworth \& Toller 1972: 137.

192 Graff 1834-1842: vol 6 771; Baesecke 1935: 19, 23, 61 \& 78; Schützeichel 1974: 174; Pokorny 1959: vol 1 959; Kluge 1899: 652; Schmidt-Wiegand 1978: 26.

193 Lexer 1872-1878: vol 1 381; His 1920: 101, 125.

194 Brunner 1906: 636; Kralik 1913: 98; Niederhellmann 1983: 219.

195 Lex Baiuvariorum 4 27: Si quis aliquem plagaverit, ut exinde claudus fiat, sic ut pedes eius ros tangit, quod taudregil vocant; and 611.

196 Lex Alamannorum 57 62: Si quis autem alium in genuculo placaverit, ita ut claudus permaneat, ut pes eius ros tangat, quod Alamanni taudragil dicunt.

197 Graff 1834-1842: vol 5346.

198 Idem: vol 2187.

199 Fick 1890-1909: vol 3190.

200 Kralik 1913: 111.

201 Lex Baiuvariorum 4 4: Si in eum vena percusserit, ut sine igne stangnare non possit, quod adarcrati dicunt.

202 Niederhellmann 1983: 234. 
or "sinew". ${ }^{203}$ However, the second morpheme cannot be compared directly with other loci, although it can certainly be stated that grammatically it is an abstract feminine noun with formation identical to the phrase marchifalli. ${ }^{204}$ It cannot be ruled out that the morpheme -crati could be related to the German word *gra or *grê (sharp, rough), which can be associated with the Indo-European root *ghre or *ghra, meaning "to rub" or "to graze heavily". ${ }^{205}$ That is where the Middle High German grât (hill, splinter), ${ }^{206}$ and, possibly, the Old High German crâti and crâtian, meaning "pricking" and "to prick" come from; accordingly, adarcrati means venae percussio. ${ }^{207}$

The phrase kepolsceni refers to an injury where the bone of the skull becomes visible. ${ }^{208}$ The first morpheme of the phrase is probably related to the Old High German gebal/kebul ${ }^{209}$ and the Middle High German gebel, meaning "skull. ${ }^{210}$ The second morpheme may be linked to the Old High German skinan or skein, meaning "to appear, to become visible"; 211 accordingly, the phrase may be translated as apparitio testae (Schädelschein). ${ }^{212}$ (The first morpheme of the phrase kepolsceni also appears independently in the lex Alamannorum in the locus concerning the medical instruments called pinn and fano. ${ }^{213}$

In the lex Baiuvariorum, plotruns means nothing else than "bleeding wound" or "flow of blood". ${ }^{214}$ Yet, the law separates it from deeper injury to a major bloodvessel, that is, adarcrati. ${ }^{215}$ The scenario itself is defined in almost all folk laws; ${ }^{216}$ the lex Ribuaria,$^{217}$ the lex Alamannorum ${ }^{218}$ and the Pactus legis Salicae ${ }^{219}$ even emphasise that this outcome may be established when blood drips to the ground. However, the folk language term is found only in the Bavarian lex. The lex Visigothorum also distinguishes injury that results in bleeding (sanguis vel libor apparet) from injury where it does not (sine sanguine). ${ }^{220}$ Etymologically, the first morpheme of the

203 Graff 1834-1842: vol 1 156; Pokorny 1959: vol 1 344; Bosworth \& Toller 1972: 9.

204 Kralik 1913: 48.

205 Fick 1890-1909: vol 3138.

206 Lexer 1872-1878: vol 1 1073; Pokorny 1959: vol 1440.

207 Kralik 1913: 48.

208 Lex Baiuvariorum 4, 4: Vel in capite testa appareant, quod kepolsceni vocant.

209 Graff 1834-1842: vol 4 127; Schade 1882: vol 1 281; Schützeichel 1974: 66.

210 Lexer 1872-1878: vol 1749.

211 Graff 1834-1842: vol 6499.

212 Kralik 1913: 91.

213 Lex Alamannorum 57 6: Si autem testa id est kebul transcapulata fuerit, ita ut cervella appareat.

214 Lex Baiuvariorum 4 2: $\mathrm{Si}$ in eum sanguinem fuderit, quod plotruns dicunt.

215 Niederhellmann 1983: 229.

216 Pactus legis Salicae 17 8-9; Lex Salica 23 1-2; Pactus Alamannorum 2 7; Lex Ribuaria 21 1; Leges Saxonum 3; Lex Thuringorum 6-7; Lex Frisonum 22 4; Lex Francorum Chamavorum 18.

217 Lex Ribuaria 2.

218 Lex Alamannorum 572.

219 Pactus legis Salicae 173.

220 Lex Visigothorum 643. 
compound is related to the Old and Middle High German word blot or bluot, ${ }^{221}$ the Old Saxon, Old Frisian and Old English blöd, the Old Norse blō and the Gothic $b l \bar{o} p$, meaning "blood". ${ }^{222}$ The second morpheme of the compound is probably taken from the Old High German, Old Saxon, Old English and Gothic verb rinnan, meaning "to flow" 223 from which the Old High German word runs (a), meaning "flow" or "stream" originated. ${ }^{224}$ In Middle High German the word appears in the form bluotruns and blottruns. ${ }^{225}$ Furthermore, it is possible to discover connections with the Middle Dutch blotrunn/blotrenn, ${ }^{226}$ the Old Frisian blodrene and blodrinse, ${ }^{227}$ the Anglo-Saxon blôdryne ${ }^{228}$ and the Old Norse blôfrâs; that is, it denotes a wound where blood flows but it does not result in a limitation of movement. ${ }^{229}$

In certain expressions in the lex Baiuvariorum the active predicate in the first person pluralis reveals that the Bavarians assisting in making the law inserted them in relevant passages as words of their own folk language. Other phrases were accompanied by the active predicate in the third person plural and the passive predicate in the third person singular or plural. These either named Bavarians as the subject or not where the text made it clear that these words were used by Bavarians to express the given meaning. We cannot find such terms among the phrases that constitute the subject of the examination of this paper. In the text of the Bavarian law it is possible to read several - not necessarily Bavarian but certainly - South German expressions as well. They may be found in identical or similar form in the lex Alamannorum and were (quoting the Bavarian form) hrevawunt, lidiscart(i), marchzand, palcprust, pulislac and taudregil. Consequently, these words were borrowed from the lex Alamannorum, more specifically its earlier version, the Chlothariana. The text of the law contains other phrases that may be only presumed to be of Bavarian origin, namely adarcrati, kepolsceni and plotruns.

\section{Conclusion}

This paper examined aspects regarding the appearance of healing, the physician, the patient as well as diseases in early medieval German legislation. The first part dwelt upon the issue of dating the sedes materiae in the German Volksrechte by comparing the Bavarian, Visigothic, Langobardic and Alemannian leges.

The second part provided a brief discussion of the issue of early medieval healing, more specifically the legal status of medicine and the physician and their

221 Graff 1834-1842: vol 3252.

222 Kluge 1899: 87; Grimm 1922: vol 2 185; Kralik 1913: 98.

223 Pokorny 1959: vol 1326.

224 Graff 1834-1842: vol 2 519; Schützeichel 1974: 155; Feist 1939: 401.

225 Lexer 1872-1878: vol 1 318; His 1920: 105.

226 Lübben 1888: vol 1365.

227 Richthoven 1840: 655.

228 Bosworth \& Toller 1972: 112.

229 Brunner 1906: 636; Kralik 1913: 98. 
appearance in legal and non-legal sources. In order to set them in the context of early medieval regulation, we had to look at how ancient medicine further developed in the Middle Ages and how healing and the medical profession were judged by the Church since the latter had a considerable influence on how the role of medicine was set out in legal sources.

The third part of the paper discussed the issue referred to in the title, namely regulation of the physician, healing, diseases, bodily injuries and injuries in general in Bavarian folk law. The sources specified four diseases that influenced capability of participating in legal proceedings and the patient's legal status in general: leprosy, various forms of mental illnesses, blindness and hernia. Here the study touched on the considerable ecclesiastical motivations for the regulation of these diseases. Similarly, in order to demonstrate the view of the various folk laws, it was unavoidable to take into account the Christian doctrine (partly rooted in ancient philosophy) regarding bodily injury causing abortion and miscarriage although these folk laws differed due to the reason for and age of their recordings.

The next part provided a brief survey of the passages of the law that (1) expressis verbis set forth the necessity of involvement of a physician in case of certain injuries, and (2) - to enable determination of the seriousness of the injury and the rate of conpositio to redress it - provide information with regard to the nature of the treatment or therapeutic method used by the physician.

Finally, using the results of German rather than Latin philology, we analysed the usual folk language, namely the German (Bavarian) names of pathographies since these terms were remains dating from a time long before the law was recorded. This analysis provided security for the application of the law in that period by imposing sanctions since the compilers deemed it safer to describe the scenarios in Latin with the addition of German terminology. This detailed microphilological analysis revealed several terms that corresponded to, overlapped with and were borrowed from scenarios in other German folk laws - primarily, but not exclusively, the lex Alamannorum, lex Visigothorum and the Edictus Rothari-and provided information on the further development of these medical legal terms.

\section{BIBLIOGRAPHY}

Amundsen, Darrel W (1971) "Visigothic medical legislation" Bulletin of the History of Medicine 45: 553-569

Arbesmann, Rudolphus (1954) “The concept of 'Christus Medicus' in St Augustine” Traditio 10: $1-28$

Baader, Gerhard (1973) "Mittelalterliche Medizin in bayerischen Klöstern" Sudhoffs Archiv für Geschichte der Medizin 57: 275-296

Baader, Gerhard (1979) "Gesellschaft, Wirtschaft und ärztlicher Stand im frühen und hohen Mittelalter" Medizinhistorisches Journal 14: 176-185

Babják, Ildikó (2005) Árucsere-ügyletek a germán népek szokásjogában [Transactions of Trade in German Customary Laws] PhD-Thesis (Miskolc) 


\section{TAMÁS NÓTÁRI}

Baesecke, Georg (1935) “Die deutschen Worte der germanischen Gesetze” Beiträge zur Geschichte der deutschen Sprache und Literatur 59: 1-101

Beek, Henri Hubert (1969) Waanzin in de middeleeuwen (Haarlem)

Benedek, István (1990) Hügeia (Budapest)

Bosworth, Joseph \& Toller, Thomas Northcote (1972) Ango-Saxon Dictonary (ed A Campbell (Oxford)

Brie, Maria (1906) "Der germanische, insbesondere der englische Zauberspruch" Mitteilungen der schlesischen Gesellschaft für Volkskunde 8: 1-36

Brunner, Heinrich (1906³) Deutsche Rechtsgeschichte vol 2 (Berlin)

Cockayne, Thomas Oswald (1965) Leechdoms, Wortcunning and Starcraft of Early England vols 1-3 repr (London)

Conrad, Hermann (1962) Deutsche Rechtsgeschichte vol 1 (Karlsruhe)

Diepgen, Paul (1922) Studien zur Geschichte der Beziehungen zwischen Theologie und Medizin im Mittelalter vol 1 (Berlin-Grünewald)

Diepgen, Paul (1949) Geschiche der Medizin. Die historische Entwicklung der Heilkunde und des ärztlichen Lebens vol 1 (Berlin)

Diepgen, Paul (1958) Über den Einfluß der autoritativen Theologie auf die Medizin des Mittelalters (Mainz)

Dilcher, Gerhard (1978) "Langobardisches Recht" in Handwörterbuch zur deutschen Rechtsgeschichte vol 2 (Berlin): 1607-1618

Du Cange, Charles du Fresne et al (1883-1887) Glossarium mediae et infimae Latinitatis vols 1-10 (Niort)

Duft, Johannes (1959) Sankt Otmar. Die Quellen zu seinem Leben, Lateinisch und deutsch (Zürich-Lindau-Konstanz)

Ebel, Friedrich \& Thielmann, Georg (2003) Rechtsgeschichte. Von der Römischen Antike bis zur Neuzeit (Heidelberg)

Eis, Gerhard (1964) Althochdeutsche Zaubersprüche (Berlin)

Fastrich-Sutty, Isabella (2001) Die Rezeption des westgotischen Rechts in der Lex Baiuvariorum (Köln)

Feist, Sigmund (1939) Vergleichendes Wörterbuch der gotischen Sprache (Leiden)

Fick, August (1890-1909) Vergleichendes Wörterbuch der indogermanischen Sprachen vols 1-3 (Göttingen)

Graff, Eberhard Gottlieb (1834-1842) Althochdeutscher Sprachschatz oder Wörterbuch der althochdeutschen Sprache vols 1-6 (Berlin)

Grendon, Felix (1909) “The Anglo-Saxon charms” J of American Folklore 22: 105-237

Grimm, Jacob (19224) Deutsche Rechtsalterthümer vols 1-2 (Leipzig)

Hansen, Joseph (1900) Zauberwahn, Inquisition und Hexenprozeß im Mittelalter und die Entstehung der großen Hexenverfolgung (München-Leipzig)

Harnack, Adolf (1892) Die griechische Übersetzung des Apologeticus Tertullians. Medizinisches aus der älteren Kirchengeschichte (Leipzig)

Hempel, Johannes (1965) Heilung als Symbol und Wirklichkeit im biblischen Schrifttum (Göttingen) 
His, Ruldoph (1920) “Die Körperverletzungen im Strafrecht des deutschen Mittelalters” Zeitschrift der Savigny-Stiftung für Rechtsgeschichte, Kanonistische Abteilung 41: 75-126

His, Rudolph (1928) Geschichte des deutschen Strafrechts bis zur Karolina (München-Berlin) Jahn, Joachim (1991) Ducatus Baiuvariorum. Das bairische Herzogtum der Agilolfinger (Stuttgart) Jörimann, Julius (1925) Frühmittelalterliche Rezeptarien (Zürich-Leipzig)

Kluge, Friedrich (1899) Etymologisches Wörterbuch der deutschen Sprache (Straßburg)

Kralik, Dietrich von (1913) "Die deutschen Bestandteile der Lex Baiuvariorum" Neues Archiv der Gesellschaft für Ältere Deutsche Geschichtskunde 38: 1-132

Landau, Peter (2004) Die Lex Baiuvariorum. Entstehungszeit, Entstehungsort und Charakter von Bayerns ältester Rechts- und Geschichtsquelle (München)

Lenel, Otto (1915) "Geschichte der Quellen des römischen Rechts" in Enzyklopädie des Rechtswissenschaft in systematischer Bearbeitung (Leipzig)

Lexer, Matthias (1872-1878) Mittelhochdeutsches Handwörterbuch vols 1-3 (Leipzig)

Lichtenthaler, Charles (1974) Geschichte der Medizin I. Vorgeschichte, Antike und Mittelalter (Köln-Lövenich)

MacKinney, Loren C (1957) "Medieval surgery" J of the International College of Surgeons 27: 393-404

Mitteis, Heinrich \& Lieberich, Heinz (1966) Deutsche Rechtsgeschichte (München-Berlin)

Morsak, Louis C (1977) “Zum Tatbestand der Abtreibung in der Lex Baiuvariorum” in L Carlen (ed) Festschrift für Ferdinand Elsener (Sigmaringen): 199-206

Nehlsen, Hermann (1972) Sklavenrecht zwischen Antike und Mittelalter. Germanisches und römisches Recht in den germanischen Rechtsaufzeichnungen I Ostgoten, Westgoten, Franken, Langobarden (Frankfurt am Main-Zürich)

Nehlsen, Hermann (1978) “Lex Visigothorum” in Handwörterbuch zur deutschen Rechtsgeschichte vol 2 (Berlin): 1966-1979

Nehlsen, Hermann (1982) “Alarich II. als Gesetzgeber. Zur Geschichte der Lex Romana Visigothorum" in Studien zu den germanischen Volksrechten. Gedächtnisschrift für Wilhelm Eber (Frankfurt am Main): 143-203

Niederhellmann, Annette (1981) "Heilkundliches in den Leges. Die Schädelverletzungen und ihre Bezeichnungen" in Ruth Schmidt-Wiegand (ed) Wörter und Sachen im Lichte der Bezeichnungsforschung (Berlin-New York): 74-90

Niederhellmann, Annette (1983) Arzt und Heilkunde in den frühmittelalterlichen Leges. Eine wort- und sachkundliche Untersuchung (Berlin-New York)

Nótári, Tamás (2010) Lex Baiuvariorum (Szeged)

Nótári, Tamás (2014) Law and Society in Lex Baiuvariorum (Passau)

Pokorny, Julius (1959) Indogermanisches etymologisches Wörterbuch vols 1-3 (Bern)

Quirin, Heinz (1950) Einführung in das Studium der mittelalterlichen Geschichte (Braunschweig)

Reier, Herbert (1976) Heilkunde im mittelalterlichen Skandinavien. Seelenvorstellungen im Altnordischen vol 2 (Kiel)

Richthofen, Karl Friedrich von (1840) Altfriesisches Wörterbuch (Göttingen)

Rothschuh, Karl Eduard (1972) “Der Krankheitsbegriff” Hippokrates 43: 3-17

Rothschuh, Karl Eduard (1978) Konzepte der Medizin in Vergangenheit und Gegenwart (Stuttgart) 


\section{TAMÁS NÓTÁRI}

Rubin, Stanley (1974) Medieval English Medicine (Newton Abbot-New York)

Savigny, Friedrich Karl von (1986) Geschichte des römischen Rechts im Mittelalter vol 2 [repr] (Aalen)

Schade, Oskar (1882) Altdeutsches Wörterbuch vol 2 (Halle)

Schadewaldt, Hans (1964) “Arzt und Patient in antiker und frühchristlicher Sicht” Medizinische Klinik 59: 146-152

August Lübben (1888) Mittelniederdeutsches Handwörterbuch vols 1-2 (Norden-Leipzig)

Schmidt, Arthur Benno (1896) Medizinisches aus deutschen Rechtsquellen (Jena)

Schmidt-Wiegand, Ruth (1978) “Alemannisch und Fränkisch in Pactus und Lex Alamannorum" in Hrsg Clausdieter Schott Beiträge zum frühalemannischen Recht (Bühl Baden): 9-37

Schmidt-Wiegand, Ruth (1979) “Die volkssprachigen Wörter der Leges barbarorum als Ausdruck sprachlicher Interferenz" Frühmittelalterliche Studien 13: 56-87

Schott, Clausdieter (1978) "Lex Alamannorum" in Hrsg Adalbert Erler, Ekkert Kaufmann, Dieter Werkmüller Handwörterbuch zur deutschen Rechtsgeschichte vol 2 (Berlin): 1879-1886

Schott, Clausdieter (1979) "Der Stand der Leges-Forschung” Frühmittelalterliche Studien 13: $29-55$

Schott, Clausdieter (1993) Lex Alamannorum. Faksimile Ausgabe des Codex Sangallensis 731 (Augsburg)

Schröder, Richard (1907) Lehrbuch der deutschen Rechtsgeschichte (Leipzig)

Schützeichel, Rudolf (1974²) Althochdeutsches Wörterbuch (Tübingen)

Schwanenflügel, Sigfrid von (1950) Die Körperverletzung in den ersten geschriebenen Rechten der Germanen (etwa 500-1300 n. Chr.) (PhD, Göttingen)

Schwind, Ernst von (1908) "Kritische Studien zur Lex Baiuvariorum II" Neues Archiv der Gesellschaft für ältere deutsche Geschichtskunde 33(2): 605-694

Siebenthal, Wolf von(1950) Krankheit als Folge der Sünde. Eine medizinhistorische Untersuchung (Hannover)

Sigerist, Henry Ernest (1923) Studien und Texte zur frühmittelalterlichen Rezeptliteratur (Leipzig)

Singer, Charles (1928) A Short History of Medicine (Oxford)

Steynitz, Jesko von (1970) Mittelalterliche Hospitäler der Orden und Städte als Einrichtungen der sozialen Sicherung (Berlin)

Tate, Joshua C (2004) "Roman and Visigothic procedural law in the False Decretals of PseudoIsidore" Zeitschrift der Savigny-Stiftung für Rechtsgeschichte, Kanonistische Abteilung 90: 510-519

Vries, Jan de (1962²) Altnordisches etymologisches Wörterbuch (Leiden)

Walde, Alois \& Hofmann, Johann Baptist (1954) Lateinisches etymologisches Wörterbuch vols 1-2 (Heidelberg)

Wilda, Wilhelm Eduard (1842) Das Strafrecht der Germanen (Halle)

Wolter, Hans (1976) “Geschichtliche Bildung im Rahmen der Artes Liberales” in Josef Koch (ed) Artes Liberales von der antiken Bildung zur Wissenschaft des Mittelalters (Leiden-Köln) 50-87

Zoepfl, Heinrich $\left(1871^{4}\right)$ Deutsche Rechtsgeschichte vol 1 (Braunschweig) 